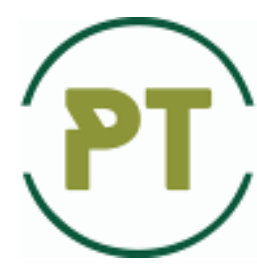

\title{
Influence of basalt fiber on tribological properties of secondary polyethylene terephthalate
}

\author{
A.-M.V. Tomina*, A.V. Yeromenko, V.S. Makarov \\ Dniprovsk State Technical University, Ukraine \\ *E-mail: an.mtomina@gmail.com
}

\begin{abstract}
The article considers the influence of discrete $(3 \mathrm{~mm})$ basalt fiber on the tribological properties of secondary agglomerated polyethylene terephthalate. It was found that the introduction of the filler reduces the coefficient of friction and the intensity of linear wear of the initial polymer 1,5 and 4,5 times, respectively, reaching the minimum values at a basalt fiber content of 5 mass. $\%$. The obtained results are due to the fact that the appearance of basalt fiber strengthens the polymer matrix that confirms the increase in hardness by $15 \%$, and inhibits the development of cracks on the surface of the composite. The study of the temperature in the contact zone showed its increase that is due to the low thermal conductivity of the filler $(0,064-0,096)$; as a result, there is an accumulation of heat in the friction zone. Further increase in fiber content (up to 10 mass.\%) leads to a sharp deterioration of the tribological and physico-mechanical properties of basaltoplastics because of the increase in the defect of the material. It is determined that the effective content of filler in the polymer matrix is 5 mass.\%. As a result, this composite was recommended for the manufacture of parts for movable joints of agricultural, automotive and metallurgical equipment.
\end{abstract}

Key words: polyethylene terephthalate, basalt fiber, coefficient of friction, intensity of linear wear, temperature in the contact zone, hardness, roughness.

\section{Introduction}

Nowadays the ecological situation in Ukraine and around the world is very close to critical. Thus, as of 2019, the volume of municipal solid waste (MSW) of polymers amounted to 215 million tons. $20 \%$ of them were sent for recycling, and only $10 \%$ were actually recycled. At the same time, 4,8 - 12,7 million tons fall into the ocean [1].

Widespread methods of the disposal of municipal solid waste, including polyethylene terephthalate (PET), are incineration, recycling, pyrolysis, decomposition and reusing. However, these methods are characterized by a number of such disadvantages as: environmental (release of toxic substances has a negative impact on the human body and the environment) and economic (periodic or semi-continuous principle of operation).

Actually, one of the common practices of the disposal of municipal solid waste is the creation of composite materials (CM) of structural (lattice drainage systems, covers and housings of hatches, bottoms of bodies and door modules of cars), general (waterproof furniture, park benches [2, 3]) and tribotechnical (gears, sliding bearings) purpose. Secondary use of MSW allows obtaining a number of such advantages as: improvement of the ecological situation, due to safe utilization of PET waste and increase of economic efficiency (the cost of secondary PET is $40 \%$ lower than the primary) [4].

Therefore, the search for new effective contains of CM, including tribotechnical purposes, on the basis of secondary waste is an urgent task for scientists. 


\section{Literature review}

In the XXI ${ }^{\text {st }}$ century much attention is paid to the possibility of recycling different polymeric materials, including polyethylene terephthalate. Recycling can reduce the negative impact on the environment and return valuable polymer raw materials to the production process.

The performance characteristics of secondary PET differ slightly from the ones of primary PET. But they have low toughness index and wear resistance. To improve the technical properties of polyethylene terephthalate, various modifiers are introduced. They are: bifunctional organic compounds, dispersed (polycarbonate, quartz glass, crushed gravel, slag, sand, fly ash) and fibrous (basalt wool, fiberglass) fillers.

Today basalt fibers (BF) are one of the promising fillers for the creation of CM. The use of BF will allow to obtain $\mathrm{CM}$ with a high indicator of wear resistance, low coefficient of thermal linear expansion, resistance to moisture, acids and alkalis. These composites can be successfully used instead of serial materials (cast iron, steel and non-ferrous alloys) in the manufacture of parts of tribological joints in the automotive, agricultural and metallurgical industries [5-7].

Given the above, the aim of the work was to study the influence of discrete basalt fiber on wear, coefficient of friction and hardness of secondary agglomerated polyethylene terephthalate

\section{Methods}

Agglomerated secondary PET was selected as the polymer matrix to create CM. Polyethylene terephthalate is a synthetic linear thermoplastic polymer that belongs to polyesters. It is characterized by [8] good heat resistance in the temperature range from 233 to $423 \mathrm{~K}$, resistance to shocks and deformations, acids, alkalis, lubricants and most organic compounds.

Basalt roving (BR) (manufacturer is PrJSC "Research Institute of Fiberglass and Fiber" (RIFF, Ukraine)) was chosen as a filler for secondary PET. It was later cut to a size of $3-4,5 \mathrm{~mm}$. Technical characteristics of BR are given in table 1 [9].

Table 1

\section{Properties of basalt roving}

\begin{tabular}{|l|c|}
\hline \multicolumn{1}{|c|}{ Indicator } & Value \\
\hline Density, $\mathrm{kg} / \mathrm{m}^{3}$ & 2700 \\
\hline The average diameter of the unit fiber, $\mu \mathrm{m}$ & 13,6 \\
\hline Linear density of a complex thread, tex & 170 \\
\hline Breaking load of roving (not less), N (kgf) & $500(50)$ \\
\hline Operating temperature, $\mathrm{K}$ & $23-923$ \\
\hline Chemical resistance (weight loss, \% after three hours of boiling) in: & 1,6 \\
$-\mathrm{H}_{2} \mathrm{O}$ & 2,75 \\
$-2 \mathrm{NaOH}$ & 2,2 \\
$-2 \mathrm{NHCl}$ & \\
\hline Thermal conductivity coefficient, W/m $\cdot \mathrm{K}:$ & 0,064 \\
- at $398 \mathrm{~K}$ & 0,096 \\
- at $573 \mathrm{~K}$ & \\
\hline
\end{tabular}

Preparation of basaltoplastics (BP) on the basis of secondary PET containing 5 - 10 mass.\% of BF was carried out in several stages. Thorough drying of PET was carried out to remove residual moisture (permissible amount was 0,02-0,5\%). It was done, because the further processing of undried PET at elevated temperatures leads to partial hydrolysis of the chains and, as a consequence, the irreversible deterioration of the physical, chemical and thermal properties of the polymer. Drying was carried out at $408 \mathrm{~K}$ in SPT-200 thermal cabinet for 3 hours. Mixing (combination) of the components was carried out in the apparatus under the influence of a rotating electromagnetic field $(0,12 \mathrm{~T})$ using ferromagnetic particles that were then removed from the composition by the method of magnetic separation. Pre-prepared prepregs were loaded into a mold heated to $383 \mathrm{~K}$, then they were heated to $533 \mathrm{~K}$ and kept at this temperature for 15 minutes without load. Next, the samples were cooled under constant load (40 MPa) to a temperature of $383 \mathrm{~K}$ and removed from the mold.

Tribotechnical characteristics in the conditions of friction without lubrication according to the "disk-pad" scheme were studied on the SMC-2 friction machine at a load of 1,0 MPa, sliding speed of 0,5 - 1,5 m/s. Steel 45 (45 - $48 \mathrm{HRC}, \mathrm{Ra}=0.32 \mu \mathrm{m})$ was used as a counterbody. The roughness of the samples was measured on 170621 profilometer using a sharp solid needle (probe), which moved on the surface of basaltoplastics and 
polyethylene terephthalate copying its irregularities. Studies of the friction surface morphology of the developed BP were performed using "BIOLAM-M" microscope. The hardness of PET and basaltoplastics based on it was determined using TD-42dynamic hardness tester [10].

\section{Results}

Analyzing the results of tribological studies, it was found that the basalt fiber reinforcement of secondary agglomerated PET leads to a decrease in the coefficient of friction (Fig. 1) and the intensity of linear wear (Fig. 2) by 1,5 and 4,5 times, respectively, reaching minimum values at the filler content 5 mass. $\%$.

It can be seen from Fig. 1 that $f(v)$ dependence is extreme, that is, in the initial period the coefficient of friction increases with increasing sliding speed, and then, reaching its maximum value, gradually decreases [11]. The increase in the coefficient of friction in the range of speeds of $0,5-1,0 \mathrm{~m} / \mathrm{s}$ is due to the increase of the friction force in the contact zone due to the frictionality of the BF. Further decrease of this indicator at a speed of $1,5 \mathrm{~m} / \mathrm{s}$ can be explained by the fact that the sample volume is dominated by the processes of destruction (brittle fracture) due to the development of defects (pores, cracks) at the "PET - basalt fiber" interface. This is confirmed by the fact that the intensity of linear wear increases sharply (see Fig. 2) at $v=1,5 \mathrm{~m} / \mathrm{s}$ [12].

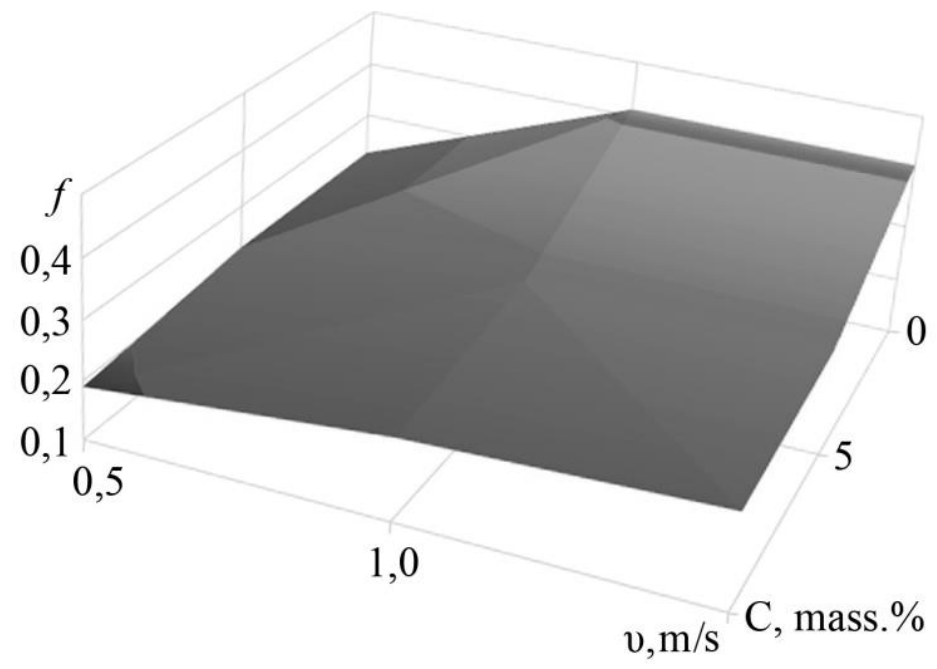

Fig. 1. Dependence of the friction coefficient of pure polyethylene terephthalate and basaltoplastics based on it on the sliding speed (specific load $P=1 \mathrm{MPa}$ )

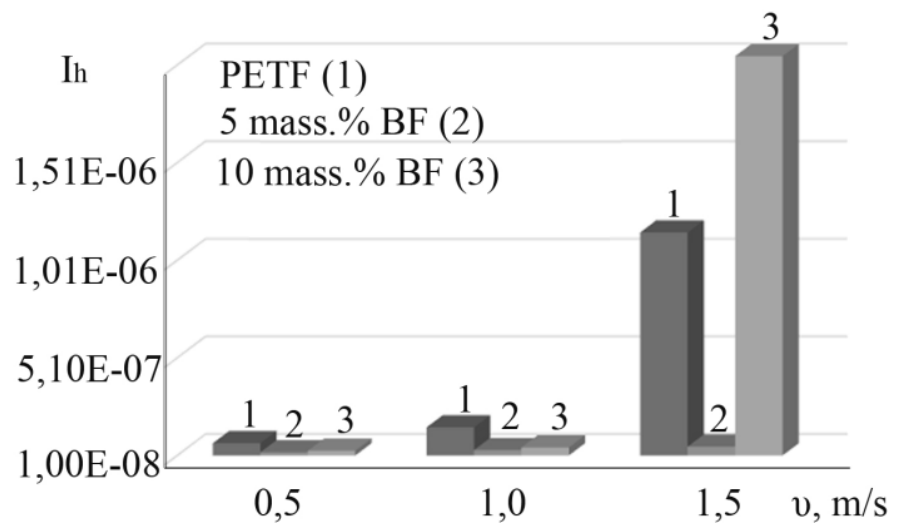

Fig. 2. Dependence of the intensity of linear wear of polyethylene terephthalate and basaltoplastics based on it on the sliding speed (specific load $P=1 \mathrm{MPa}$ )

As for the temperature in the contact zone (see Fig. 3), it was found that the introduction of basalt fiber leads to its growth by an average of $15 \%$. This can be explained by the fact that the basalt fiber has a low thermal conductivity (see table 1) and, as a consequence, insufficient temperature removal from the contact zone. Reducing the temperature can be achieved by introducing fillers with high thermal conductivity. They can be: graphite, nickel, aluminum, copper, carbon and organic fibers. 


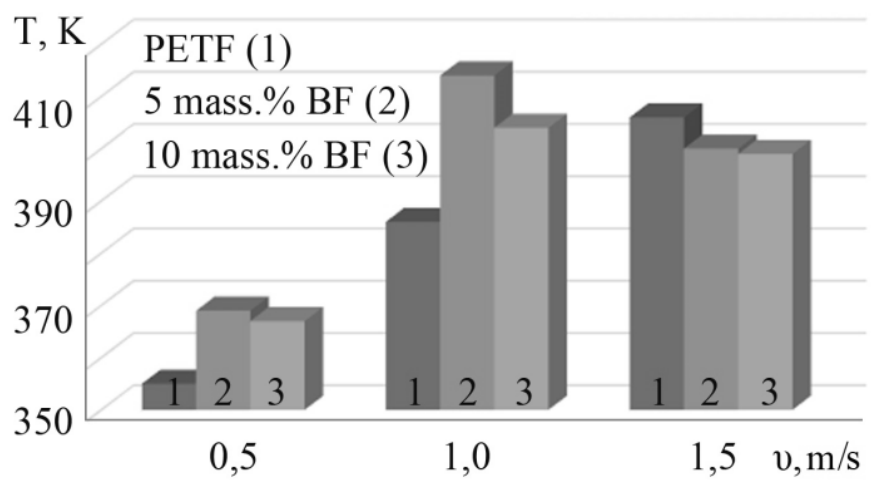

Fig. 3. Dependence of temperature in the contact zone of polyethylene terephthalate and basaltoplastics based on it on the sliding speed (specific load $P=1 \mathrm{MPa}$ )

The study of the morphology of the friction surfaces showed (Fig. 4) that the introduction of basalt fiber reduces the depth of abrasion tracks by $40 \%$ (roughness of BP). Strengthening of BP is due to the fact that basalt fibers due to high technical characteristics complicate the movement of dislocations in the polymer binder under the action of the applied load. Confirmation of this is an increase in the hardness of polyethylene terephthalate by $15 \%$.

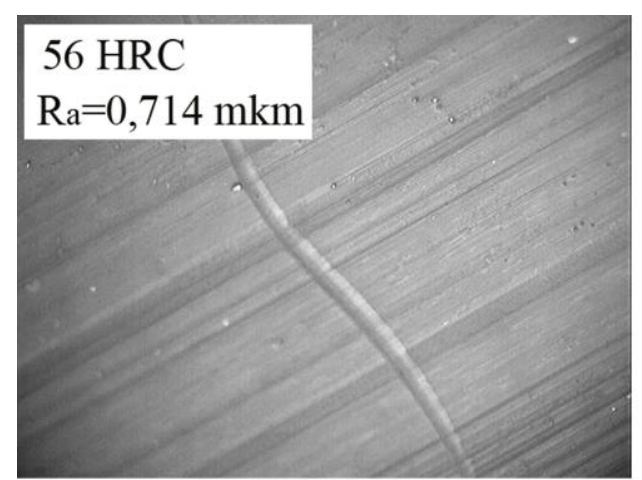

a

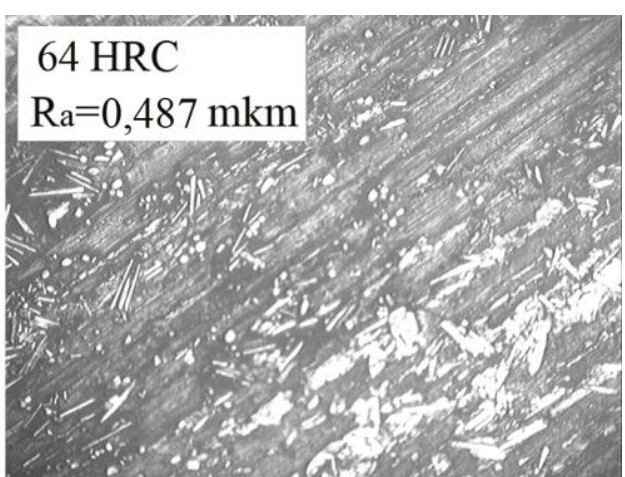

$\mathbf{b}$

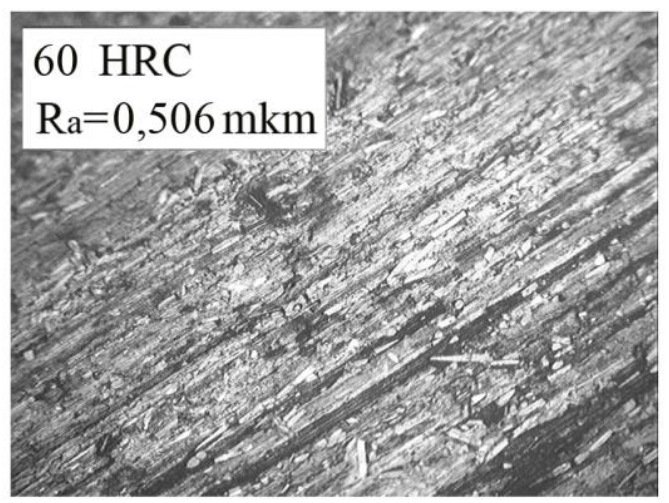

c

Fig. 4. Microstructure $(\times 100)$ of the friction surface during wear of polyethylene terephthalate (a) and basaltoplastics based on reinforced with 5 (b) and 10 (c) mass.\% of fibers (specific load $P=1 \mathrm{MPa}$, sliding speed $v=1 \mathrm{~m} / \mathrm{s}$ )

From the above data it can be seen that the tribological properties and hardness improve only when the $\mathrm{BF}$ content is 5 mass. \%, and with its further increase to 10 mass.\% there is a sharp decline due to the growth of defects in the volume of the composite. This is confirmed by the fact that the calculated density of basaltoplastics (Fig. 5) containing 5 mass.\% of fiber is less than the experimental density, and at 10 mass.\% of fiber it is higher than hydrostatic one [13]. 


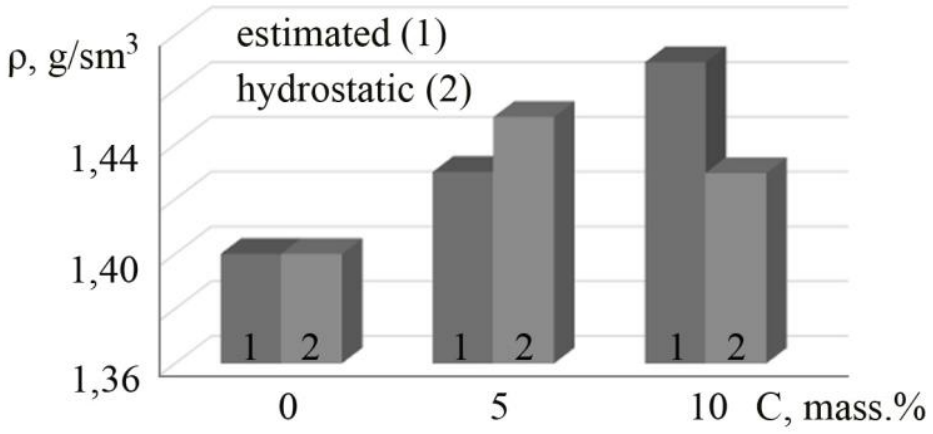

Fig. 5. Dependence of calculated

and hydrostatic density of polyethylene terephthalate on the content of basalt fiber

This can be explained by the fact that at a basalt fiber content of 5 mass.\% the process of ordering polyethylene terephthalate prevails over loosening at the "matrix - fiber" interface, and at a content of 10 mass.\% it is vice versa.

\section{Conclusions}

Analysis of the results of the research (tribological and physico-mechanical) of the developed CM showed that the use of discrete basalt fiber as a filler for secondary PET is a promising way to increase wear resistance by 4,5 times and reduce the coefficient of friction by $50 \%$. BP with effective filler content was recommended for the manufacture of plain bearings for automotive, agricultural and metallurgical industries.

\section{References}

1. Voprosy razvitija vtorichnoj pererabotki PJeT v uslovijah transformacii sfery obrashhenija s othodami $\mathrm{v}$ kontekste mirovyh jekologicheskih tendencij 2020 [Development of PET recycling in the context of transformation of the waste management industry in the context of global environmental trends in 2020]. Elektronnij resurs - Rezhim dostupu: https://www.refinitiv.ru/blog/market-insights/voprosy-razvitija-vtorichnojpererabotki-pjet-v-uslovijah-transformacii-sfery-obrashhenija-s-othodami-v-kontekste-mirovyh-jekologicheskihtendencij-2020/

2. Kashparov I.I., Klushin V.A., Vinokurov I.P., Zubenko A.F., Kashparova V.P., Smirnova N.V. (2017). Kompozicionnye materialy na osnove othodov sel'skogo hozjajstva, proizvodstva 5-gidroksimetilfurfurola i polijetilena [Composite materials based on agricultural waste, production of 5-hydroxymethylfurfural and polyethylene]. Al'ternativnaja jenergetika i jekologija. (19-21), 116-125.

3. Korin'ko I.V., Goroh N.P., Kovalenko A.N., Timoshenko V.V., Jaroshenko Ju.V. (2006). Perspektivy ispol'zovanija polimernyh kompozicionnyh materialov [Prospects for the use of polymer composite materials]. Kommunal'noe hozjajstvo gorodov, 67, 56-64.

4. Ershova O.V., Ivanovskij S.K., Chuprova L.V., Bahaeva A.N. (2015). Sovremennye kompozicionnye materialy na osnove polimernoj matricy [Modern composite materials based on a polymer matrix]. Mezhdunarodnyj zhurnal prikladnyh i fundamental'nyh issledovanij. № 4-1, 14-18.

5. Arlamova N.T., Burmistr M.V., Hohlova T.V., Rozgon O.V., Soroka M.L. (2012). Jekologicheskie aspekty perera-botki othodov polijetilentereftalata [Environmental aspects of recycling polyethylene terephthalate waste]. Vestnik DNUZhT. 146-149.

6. Evmenov S.D., Silinina E.B., Smirnov A.V. (2004). Issledovanie processa poluchenija vtorichnogo polijetilentereftalata i kompozicionnyh materialov na ego osnove [Investigation of the process of obtaining secondary polyethylene terephthalate and composite materials based on it]. Vestnik Kuzbasskogo gosudarstvennogo tehnicheskogo universiteta. 62-65.

7. Petrova P.N., Sokolova M.D., Zarovnjaev B.N., Majer A.F., Gogoleva O.V., Vasil'ev S.V. (2014). Perspektivnost' ispol'zovanija bazal'toplastikov dlja gornoj promyshlennosti [Prospects for the use of basalt plastics for the mining industry]. Gornyj informacionno-analiticheskij bjulleten' (nauchno-tehnicheskij zhurnal. 413-419.

8. Kirsh I.A., Chalyh T.I., Anan'ev V.V., Zaikov G.E. (2015). Regulirovanie fiziko-mehanicheskih svojstv vtorichnogo polijetilentereftalata putem himicheskoj i fizicheskoj modifikacii [Regulation of the physical and mechanical properties of secondary polyethylene terephthalate by chemical and physical modification]. Vestnik tehnologicheskogo universiteta. 18, 7, 79-82.

9. Basalt roving [Echo-pulse method]. Elektronnij resurs - Rezhim dostupu: http://niisv.com.ua/ru

10. Burya O.I., Tomina A.-M.V., Yeriomina Ye., Tomin S.V. (2019). The impact of organic fibers on the tribotechnical properties of phenylone aromatic polyamide. Problems of Tribologyy, 24 (3/93), 68-73. 
11. Shelkovoj A.N., Mironenko E.V., Klochko A.A. (2013). Kriterii formirovanija struktur i parametrov sistem obrabotki, obespechivajushhih zadannye jekspluatacionnye svojstva zakalennyh krupnomodul'nyh zubchatyh koles [Criteria for the formation of structures and parameters of processing systems that provide the specified performance properties of hardened large-modular gears]. Suchasni texnologiyi v mashy`nobuduvanni. $8,185-200$.

12. Alisin V.V. (2019).Cirkonievye keramicheskie materialy tribotehnicheskogo naznachenija [Development of science and education]. Razvitie nauki i obrazovanija. 5-16.

13. Tomina A.-M. (2019). Vstanovlennia zakonomirnostei vplyvu orhanichnykh volokon na vlastyvosti ta strukturu aromatychnoho poliamidu fenilon [Establishing patterns of influence of organic fibers on the properties and structure of aromatic polyamide phenylone]. Candidate's thesis. Kamianske. 
Томіна А.-М.В., Срьоменко О.В., Макаров В.С. Вплив базальтового волокна на трибологічні властивості вторинного поліетилентерефталату.

Зростання обсягів споживання композиційних матеріалів, зокрема триботехнічного призначення, в багатьох галузях сучасної промисловості потребує розробки нових зносостійких матеріалів, здатних до тривалої експлуатації. Використання твердих побутових відходів для виготовлення композиційних матеріалів, зокрема поліетилентерефталату, дозволяє отримати ряд переваг: екологічний аспект, попит споживачів і низьку вартість сировини. У статті розглянуто вплив дискретного базальтового волокна на трибологічні властивості вторинного агломерованого поліетилентерефталату в умовах тертя без змащення за схемою «диск-колодка». Встановлено, що введення наповнювача призводить до зменшення коефіцієнту тертя та інтенсивності лінійного зношування вихідного полімеру в 1,5 та 4,5 рази відповідно, сягаючи мінімальних значень при вмісті базальтового волокна 5 мас.\%. Отримані результати обумовлені тим, що поява базальтового волокна зміцнює полімерну матрицю, а це в свою чергу підтверджує зростання твердості на $15 \%$ і гальмує розвиток тріщин на поверхні композиту (шорсткість зменшується на 40 \%). Дослідження температури в зоні контакту показало іiі збільшення, що зумовлено низьким показником теплопровідності наповнювача $(0,064$ - 0,096). В результаті цього в зоні тертя відбувається накопичення теплоти. Подальше збільшення волокна (до 10 мас.\%) призводить до різкого погіршення трибологічних i фізико-механічних властивостей базальтопластиків, що спричинено зростанням дефективності матеріалу. Визначено, що ефективний вміст наповнювача в полімерній матриці складає 5 мас.\%. Внаслідок чого даний композит був рекомендований для виготовлення деталей рухомих з'єднань аграрної, автомобільної та металургійної техніки.

Ключові слова: поліетилентерефталат, базальтове волокно, коефіцієнт тертя, інтенсивність лінійного зношування, температура в зоні контакту, твердість, шорсткість. 